\title{
Land Use Pattern, Drainage System and Waste Management of Saint Martain's Island: A Geo-Environmental Study
}

\author{
Muhibbullah $^{1} \&$ Iqbal Sarwar ${ }^{1}$ \\ ${ }^{1}$ Associate Professor, dept. of Geography and Environmental Studies, University of Chittagong, Bangladesh \\ Correspondence: Muhibbullah, Associate Professor, dept. of Geography and Environmental Studies, University \\ of Chittagong, Bangladesh. E-mail: iqbalsrwr@yahoo.com
}

Received: October 19, 2017

Accepted: November 7, 2017 Online Published: November 30, 2017

doi:10.5539/jgg.v9n4p69

URL: http://dx.doi.org/10.5539/jgg.v9n4p69

\begin{abstract}
Saint Martin's island is one of the unique coral islands and popular tourist destinations in Bangladesh due to its location and favourable environmental condition. The present study has been taken to know the present and past land use pattern, and to explore the existing drainage system and wastes management of Saint Martin's island in Bangladesh. To achieve the goals of the study, both primary and secondary data have been collected and incorporated. Primary data have been collected through field observation, questionnaire survey, and focus group discussion (FGD). Total 200 questionnaires have been conducted by random sampling during summer and winter season in the year of 2015. Secondary data were also collected from various official records and related researchers' publications and articles. It is observed from the study that land use pattern of Saint Martin's island has already been changed and still changing randomly due to increase of inhabitants, settlers and tourists. Most of the agricultural land and vacant lands are going to turn into the hotels, resorts and other human settlements. There is no structural drainage system in this Island. Moreover, most of the wastes are going to be produced by the tourists, fishermen, hotels and restaurants. The present study suggested taking necessary initiate through solving the waste mismanagement problem and proper drainage system for this unique coral island.
\end{abstract}

Key words: land use, drainage, waste, management, Saint Martian's island, Bangladesh

\section{Introduction}

Saint Martin's island is the only coral island and a unique tourist place of Bangladesh. It is also recognized as the richest biodiversity hotspot in terms of marine biotic resources in Bangladesh (Upal, 2015). The Saint Martin's island exposes a sequence of marine sedimentary rocks ranging in age from late Miocene to present (Rashid and Rob, 1997). The southern part of this island was formed presumably in late Miocene age, the most important land is overlain by coquina bed was formed in the Pleistocene age, and alluvium and beach sands was formed in the Holocene age (Hoque et al., 1979). The Saint Martin's island presents a variety of physiographic features, namely; rocky platform, sandy beach, sand dune, lagoon, marshes, tom-bolo, crenulated shoreline, and coral clusters. The rocks are consisting with argillaceous limestone, calcareous sand stones, fossiliferous conglomerates and Caroline limestone (Hossain et al., 2007). A rim of sand dunes in the north, southwest and western sides of the island characterizes the shoreline. The island comprises with subtropical monsoon climate that prevails also all over Bangladesh.

The island is an endowed with vast marine and land resources having global biodiversity significance. The island is a good example of co-occurrence of corals, algae, seaweeds, grasses and mangroves (UNDP, 2010). The Saint Martin's island has great contribution on tourism sector in Bangladesh. It is also treated as an ideal site for fishing zone that provides a variety of marine fish species. Hossain et al., (2007) stated that about 1650 Metric Tons (MT) of marine fishes are being caught in every year. There are about 234 species of fish, 66 species coral (36 are found living), 187 species crab 14 species of algae have been recorded from this island (Hossain and Islam 2006). The major macro-invertebrate communities of this island comprises with about 61 species of mollusks, 9 species of echinoderms, 4 species of Zoanthids and 4 species of Bryozoans (Tomasick, 1997; NCSIP, 1997).

The ecosystem of Saint Martin's island is blessed of nature with vast resources but these resources are facing threats day by day due to natural calamities, various types of pollution, and other anthropogenic activities (Upal, 2015). Over exploitation of renewable marine and coastal resources (e.g. rocky reef fisheries, coral and shell 
extraction, removal of coastal vegetation from inter-tidal and sub-tidal habitats) are treated as the major threats for marine ecosystem of the island. Destructive fishing practices, mainly the use of rock-weighted gill nets over the inshore boulder reefs are one of the prime aggravates (Hossain and Islam, 2006). The environmental quality and ecological value of this island is regularly degrading by the increasing of human intervention and natural disasters in every year. There are several authorities are tried to concern about the sustainability of waste management, drainage system and water quality problems for the island (Rahman, 2009). It may definitely append to increase of solid wastes by rising of visitors or tourists into the Saint Martin's island that is also future threat for the coral habitat. The physical action of wastes throwing by tourists either on the beach or in the water might not be an apparent threat. The Marin park islands would have coped with the waste problem from the local inhabitants of the islands as well as with the increased amount of wastes from hotels, lodges, and resorts. At present, solid wastes disposal system remains absent (UNDP, 2010). Sometimes oil pollution is created by the passenger engine boats, ships; fishermen's boats are contributing for deterioration of water quality of the island. The cumulative effects of the oil residues could also affect on the health of the marine resources. Snorkeling and scuba diving are the most popular activities that tourists are tried to enjoy during their visit to the marine park of the island also. These types of activities, which are identified to pose with significant threat to the living corals in shallow water. Thus, inexperienced snorkelers and scuba divers are tending to either crush or stand on the reefs. The coral breakage could be the result of diving activity as well as anchoring of boats by the irresponsible boat operators or illegal fishermen. Sometimes, the ill-motivated visitors were tried to engage on illegal activities, such as; stealing live corals and other marine lives from the island to sell them for souvenirs all the year round. Though tourists are also prohibited from fishing within the marine parks limit but some bodies are associated with this illegal activity with the help of local administrative authority. Besides this, land use practices of the island are going to change through the increase of new population, settlers, tourists, as well as businesspersons. The present status of agricultural practices, available arable land, and food production is reducing rapidly due to excessive population pressure, increasing settlements, infrastructures and salinity intrusions into the main land of the island (Upal, 2015). It may be pointed 37\% area was used as agricultural land in the year of 2006 but after two years the agricultural crop lands were decreased by 4 percent and turned into $33 \%$ in the year of 2009 (The Daily Star, 2009). Nevertheless, Saint Martin's island attracts more than thousands of local and foreign visitors every day due to its panoramic beauty and immaculate marine life. Though local and foreign tourists are going to increase massively from last few decade but the fragile ecosystem of this island is not well equipped to handle this excessive tourists' crowdedness. It may mentionable that local government officials are impressed to see this islands' success with more tourists. Alam et al. (2015), mentioned that about 3000 tourists were visited in every working day and about 5000-7000 tourists were visited only in holy days and about 2000 tourists were staying there minimum one day package tour by different hotels, motels and cottages facilities during the winter season. Tourists and visitors are tempted to visit here and there in the whole island in every moment. They also produce many wastes and create deafening atmosphere through shouting for enjoyment by their own way. Though it is requested to tourist and visitors to be calm and quiet between 20:00 to 22:00 hours (because of 20:00 to 22:00 hours are emerging time for turtles into the nest) but most of the residences and visitors are not aware or conscious (Islam, 2002). Bangladesh has no significant tourist industry. It is mentionable that Government of Bangladesh has declared the island as an 'Ecologically Critical Area (ECA)' with other five ECA's and proposed a number of guidelines for sustainable management of these areas (MoEF, 1997). Development of small-scale community based ecotourism to satisfy national demand for new travel destinations may another available option for the unique island that needs to be promoted. It is also mentionable that due to geo-environmental limitations (e.g. limited supply of fresh water, cyclone prone area, coral habitant, and distance from main land etc.) large-scale tourism development is not suitable for the island. Therefore, the implementation of 'Ecotourism project' may possible with active participation of local people and effective protected area management plan. It is very important to identify the impacts of manmade various activities, which is responsible to create vulnerability for coral ecosystem. Therefore, the present study needed to construct the phenomena that relevant to the land use pattern, existing drainage condition, and waste management system that will be reflected the present geo-environmental condition and changing status of Saint Martin's island in Bangladesh.

\section{Materials and Method}

\subsection{Selection of the Study Area}

The Saint Martin's Island, locally called 'Narikel Jinjira' is located in the northeast of the Bay of Bengal (Figure.1). The island is an administrative union of Teknaf Upazila under Cox's Bazar district in Bangladesh. It is situated on $9 \mathrm{~km}$. south of the Cox's Bazar-Teknaf peninsular tip and about $8 \mathrm{~km}$. west of the north-west coast of Myanmar at the mouth of the Naaf River (Rashid and Rob, 1997). The island lies between $20^{\circ} 34^{\prime}$ to $20^{\circ} 39^{\prime} \mathrm{N}$ 
latitude, and $92^{\circ} 18^{\prime}$ to $92^{\circ} 2^{\prime}$ E longitude (Asiatic Society of Bangladesh, 2015). The total area of the island is about 14 sq. km. including 6 sq. km. consists with the rocky platforms extending into the sea (Alam et al., 2015). The Saint Martin's island is divided into 3 administrative wards and 7 local units (7 units are locally called Para; Para is a village) namely; Uttar Para, Poschim Para, Purba Para, Maddam Para, Kona Para, Gala Para, Daskin Para and Kata Bonia para.

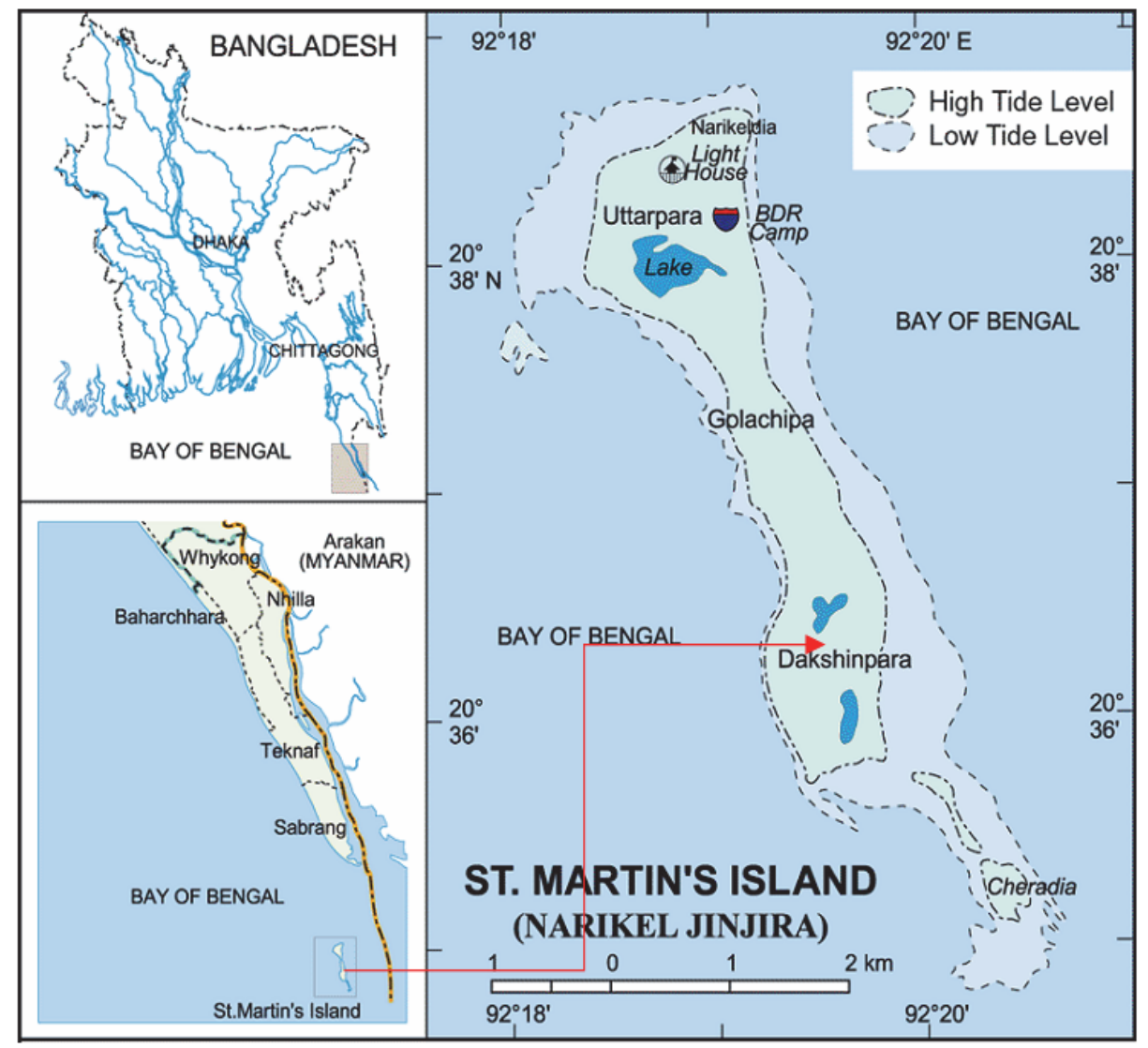

Figure 1. Location and map of the study area

Source: Asiatic Society of Bangladesh (2015)

\subsection{Data Collection and Analysis}

Basically, the present study was carried out by the combination of primary and secondary data to explore the issues related on the Island. Primary data have been collected through questionnaire survey, field observation and Focus group discussion (FGD). About 200 questionnaires have been conducted through random sampling technique from different groups as stakeholders (i.e. Local people, Tourist, businesspersons, GO and NGOs officials, Local Union Parisads' Member and Chairman etc.). The questionnaires constructed by open and close questions along with pre-coded and coded manner. Two FGD have been conducted to crosscheck the findings of the questionnaire survey. A participatory observation was also done to know the daily life style of the local people and also the tourists or visitors along with waste management system in the island. The Secondary data also incorporated from the Union Council office, Upazila Local Government Department (LGED) office and related published papers, articles, books, magazines, newspaper and other online publications regarding the issue. The collected data were analyzed by sequential manual and digital formats. Finally, the help of statistical tools like, diagrams, tables, and charts to arrange the paper presented data.

\section{Results and Discussion}

\subsection{Previous Land Use Scenerio of the Saint Martin's Island}

The Saint Martin's island was covered with rainforest, coconut trees and an abundance of teak trees before 1980s (Tomascik, 1997). The earlier communities of the islands' were dependent on the extraction of teak timber and the first wave of deforestation of the original forest taken place during the 1920s (Alam and Hasan, 1998). They 
were used to cut various trees and sold to Myanmar for building house and woody boat (Rashid and Rob, 1997). A further wave of deforestation of this island started in the 1940s through conversion of lands to cultivate paddy and nut and watermelon. Another wave of deforestation started through destroying original forest in the island during 1980s (Rashid and Rob, 1997). The various large-scale deforestation waves from the last 150 years are responsible for elimination of the original biodiversity and wildlife of the island. Therefore, the shallow water benthic communities, including the coral and other floral species destroyed in course of time (Hossain et al., 2007). Bangladeshi citizens started to settle themselves into the island during the year of 1980 through destroying the biodiversity of this unique island (Tomascik, 1997). After a few years, fishing and agriculture turned into the common profession for the new settlers.

\subsection{Present land use condition}

The present land use pattern of the island is observed through field observation and secondary sources. The observed land use types from the present study, found as agriculture, human settlement, forest with coconut, screw pine (locally it is called Keya) and mangrove forest. The surrounding coral reef of the island has an extension at southern part named 'Chera Dwip' [an extended island]. It is covered with small bushes and coconut trees, which is the only green part of the island with natural beauty. People do not usually live on this part. The sea turtles were caught sometimes by the fishermen as a food item. However, there is no prescribed or planned land use for this unique coral island. Businesspersons or outsiders with high price from the local habitants have grabbed a vast area of land of this island. A comparative scenario of land use changing condition of Saint Martin's island has been shown in the following Table.1 and Figure.2.

Table 1. A comparative scenario of land use changing condition of Saint Martin's island during 2009 to 2015

\begin{tabular}{llll}
\hline Present Land use pattern (2015) & & \multicolumn{2}{l}{$\begin{array}{l}\text { Land use pattern according to National Food Policy } \\
\text { Capacity Strengthening Program (NACOM) }\end{array}$} \\
\hline Land use type & $\begin{array}{l}\text { Land covered } \\
\text { area (\%) }\end{array}$ & Land use type & Land covered area (\%) \\
\hline $\begin{array}{l}\text { Agriculture (including paddy, dry } \\
\text { crop, potato, nut, and other crops) }\end{array}$ & 29.00 & Agricultural Land & 33.00 \\
$\begin{array}{l}\text { Human Settlement (including hotels, } \\
\text { residential, roads, commercial etc.) }\end{array}$ & 17.00 & Settlement & 8.00 \\
$\begin{array}{l}\text { Coral zone } \\
\text { Sandy shore coast }\end{array}$ & 31.00 & Coral reef & 34.00 \\
$\begin{array}{l}\text { Rocky shore coast } \\
\text { Pond and wet land }\end{array}$ & 10.00 & Sandy coast & 15.00 \\
$\begin{array}{l}\text { Forest and vegetation } \\
\text { Bird species zone }\end{array}$ & 4.00 & ----- & -- \\
$\begin{array}{l}\text { Total } \\
\text { Source: Field Survey, (2015); Union } \\
\text { record, (2015) }\end{array}$ & 5.00 & Council office & Source: Feeroz, (2009); NACOM, (2009) \\
\hline
\end{tabular}

It is observed from the above table 1 that the land use condition of the island have been changed through human settlements from 2009 to 2015,where agricultural lands are decreased. Most of the sea shore of Saint Martin's coast was occupied by the sandy shore (10\%) and rocky shore (4\%) near the Jetty area and 'Chera Dwip' (Table.1). Though Saint Martin's island is famous for coconut trees but this tree forest area is also reducing gradually. It is pointed from the above table 1 that about $2 \%$ land area of coconut forest was decreased during the period of 2009 to 2015. Alam et al., (2015) also observed that human settlement have been replaced instead of forest and vegetation through unplanned way in the Saint Martin's island. 


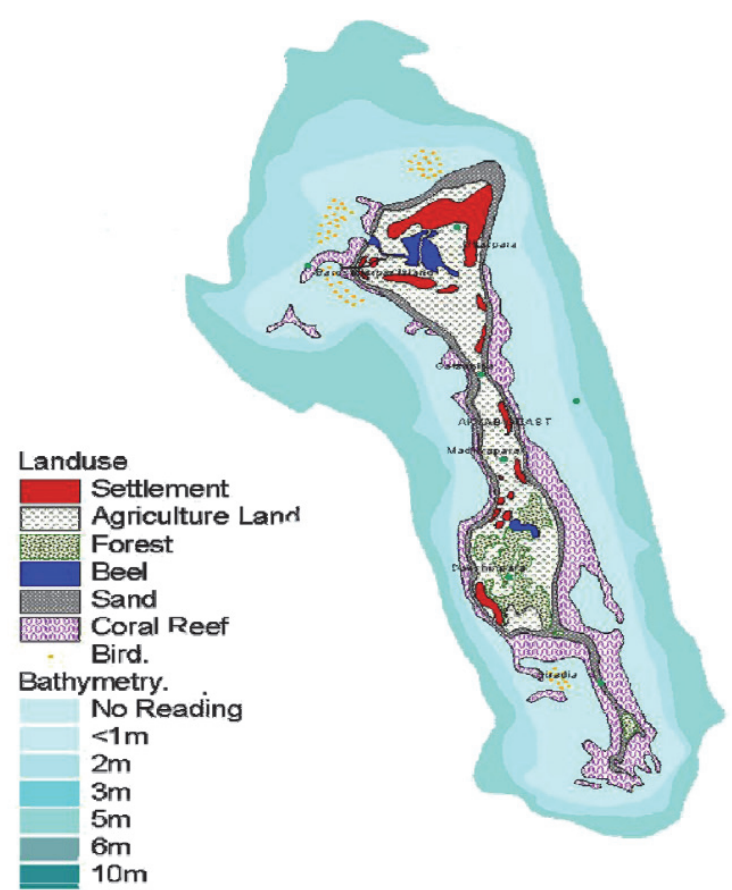

Figure 2. The major land use map of Saint Martin's island

Source: Feeroz, (2009)

It is observed from the above fig. 2 that agricultural land use was covered about $33 \%$ in 2009 s. The present study claimed that agricultural practices, available arable land and crop production is reducing rapidly due to excessive population pressure, increasing settlements and infrastructures. POUSH (2006) also observed that the available agricultural land was almost $37 \%$ of the total land in the island in 2006 . Actually, the land use pattern is changing day by day continuously in this coral island.

\subsection{Major Causes of Land Use Changes}

There are many causes are identified behind the changes of land use pattern in Saint Martin's island. The identified major causes of land use changes in the study area are shown in the following figure 3.

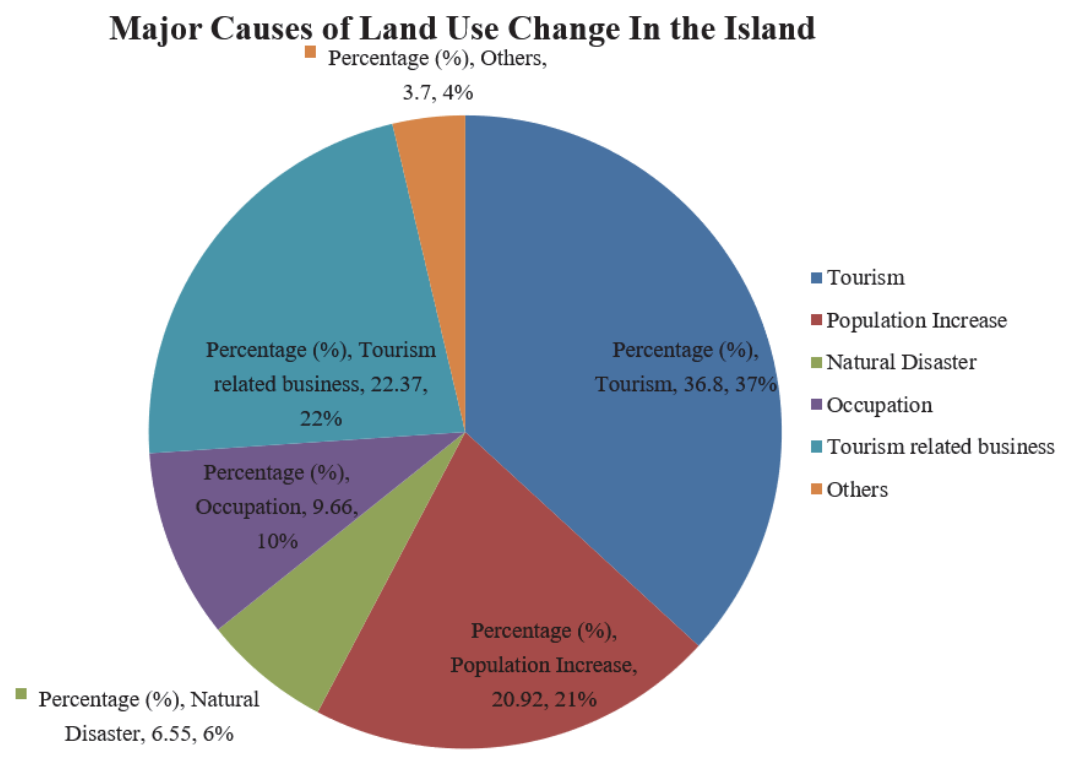

Figure 3. Major causes of land use change in Saint Martin's island

Source: Questionnaire survey, (2015) 
It is observed from the above figure 3 that the tourism (37\%) is the main responsible casual factor for changing the land use pattern of the island area. The other causes are tourism related business $(22 \%)$, population increase (21\%), occupation $(10 \%)$, and natural disaster $(6 \%)$ observed from the present study. The changing trend of land use pattern in Saint Martin's island is to be continued with the changing situation there. Rabby (2016) also found that tourist and commercial settlements are the major causes for land use changes in the Saint Martin's island.

\subsection{Drainage Condition of Saint Martin's Island}

Drainage system refers to a system of watercourses or drains for carrying off excess water from various sources. The primary benefit of natural drainage is to control of excess soil water and accumulation of excess salts in the crop root zone particularly, in the island (Hossain and Islam, 2006). Actually, there is no drainage system in the Saint Martin's island. It is observed from the present study through questionnaire survey and observation that Saint Martin's island is fully dependent on natural drainage system because of its location, tidal influence and other factors. For this reason, many problems are arising due to congestions of wastes through natural drainage system in the island. It is also observed from the present study that $55 \%$ respondents were habituated to throw household or residential wastes on road sides, $10 \%$ respondents habituated to throw agricultural wastes on nearest wet lands and 35\% respondents were habituated to throw fishing wastes to beach area within the island.

\subsection{Effects of Unplanned Drainage System in the Island}

There are several effects are found due to unplanned and haphazard drainage system in the Saint Martin's island are shown in the following figure 4.

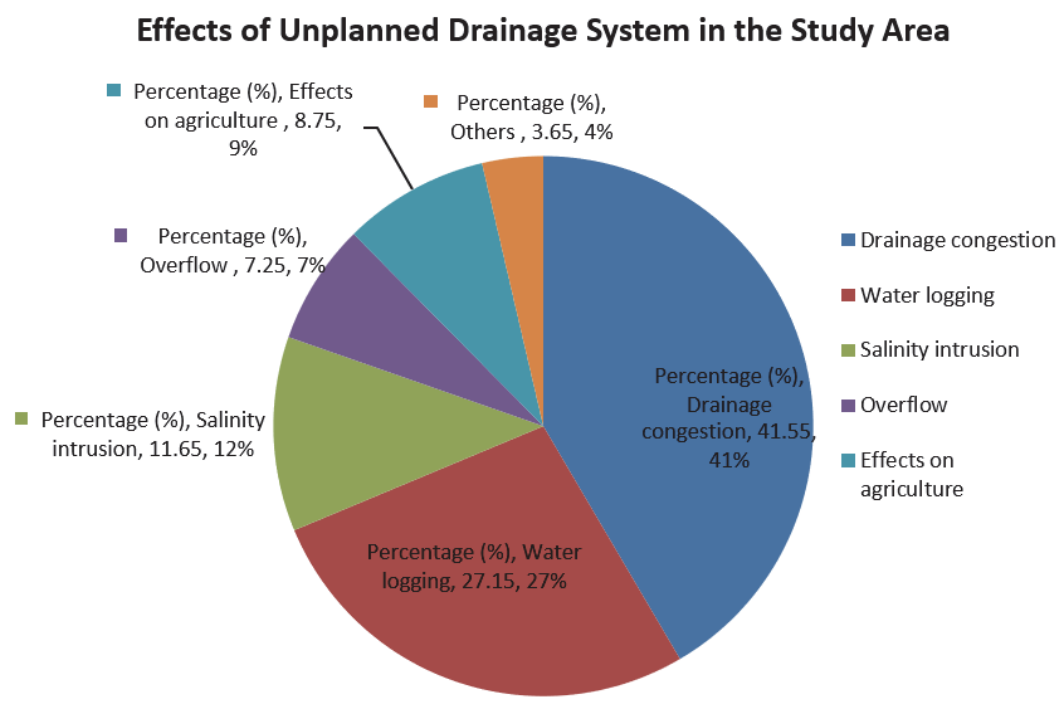

Figure 4. Effects of unplanned drainage system in the study area

Source: Questionnaire survey, (2015)

The above fig. 4 is indicated that the drainage congestions (41\%) are treated as the major effect and problem faced by the inhabitants and tourist due to the unplanned drainage system. On the other hand, $27 \%$ respondents reported the water logging is another problem due to the unplanned drainage system and $12 \%$ respondent reported the salinity intrusion is also a problem due to absent of drainage system in the island (Fig. 4). It is also reported that the winter season is the most polluted period due to drainage congestions. Afrin et al., (2013) also reported that various environmental effects are related by the unplanned drainage system in the Saint Martin's island of Bangladesh.

\subsection{Waste Management in Saint Martin's Island}

Saint Martin's island is facing tremendous problems by the increasing amount of waste due to increase of population and tourists also. It is observed from the present study that there is no structured waste management system for this island. As a result, the only coral-bearing island of Bangladesh is facing an ecological disaster due to excessive tourism and unplanned wastes disposal. Even the very existence of this newly developed island, which is almost 150 years old and small, is going to be threatened by unlimited and unfriendly tourism activities. It is also implicated form experts' opinion that the fragile eco-system of the island cannot sustain by this type of 
mass tourism. The Saint Martin's coral island is suitable only for sustainable and responsible eco-tourism. That is why; due to onslaught of mass tourism, sewage and waste disposal in the island are placing heavy burden. It is also observed that the tourist hotels' sewerages lines are connected with the direct seawater. As a result, it may be polluted the surface water and can affected in the aquatic ecosystem and biodiversity of the island.

The collection of corals and shells for souvenirs by the tourists is also pretense a threat to coral colonies of the island. The disposal of plastic materials like poly-bags, plastic bottles etc. by the tourists in and around the island are treated as harmful for the corals. Hotels in the islands are responsible to creates noise and lighting hazard in the nearby sandy beach, which are used as a nesting ground of turtles. It is observed that excessive light, noise turtles are encountering disturbance, and they go back to sea without laying eggs. The tourist season and nesting season of turtles are almost same and co-inside with each other. Moreover, the tourists are used to create noise, and habituated to enjoy fire camping for fun at night thus disturbing for the sea turtles. Numerous engine driven boats bring tourists to the island. The discharge of liquid pollutants such as oil, exhausts from the engine boats near coral sanctuary areas, is causing irreparable harm to the corals. Tourist boats anchoring at the island cause direct damage to the boulder reef.

Almost invariably, the waste management demands of these high-density, low-income settlements are inadequately served or neglected altogether even though these areas have the greatest need for these services. There is limited space of this small coral island for waste burial or composting and inhabitants are unable to make alternate arrangements to dispose of wastes. Collection of wastes are not possible to carry out in the unplanned settlements of the island and also scarcity of space for refuse containers due to narrow roadways, steep gradients and un-surfaced roads and absent of vehicles. Therefore, wastes were being dumping into open spaces, besides roads, or in wetlands where disease can vector breed. Waste clogs drains can create flood and stagnant nurseries for mosquito carrying malaria and dengue fever. Animals and waste pickers scatter the waste and leach from garbage heaps percolates into soil and waterways. In this way, this type of wastes can be contaminated food, water, soil, and health implications particularly, for the most vulnerable group such as children and the elderly. Rajasuriya et al., (2000) observed that this kind of environmental degradation could be affected negatively on tourism and local economy in the South Asian country. The present study identified several types of wastes which are produced regularly in the island are shown in the following figure 5.

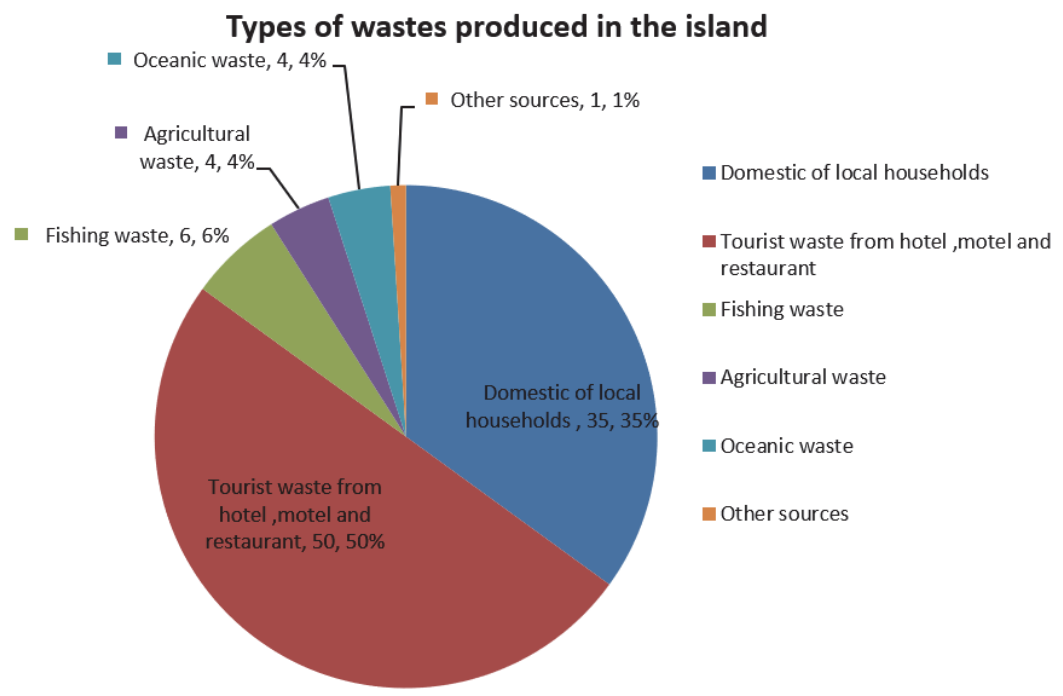

Figure 5. Types of wastes that are produced regularly in the island

Source: Field Survey, (2015)

It is observed from the above fig. 5 that about $50 \%$ wastes were being producing by the tourists though their unconsciousness food behaviors including residential hotels and restaurants. Besides it, $35 \%$ wastes were being producing from domestic from local household, $6 \%$ wastes were being producing from fishing and $4 \%$ are generated from agricultural wastes in the study area (Fig. 5). Hasan, (2009) also found that solid wastes disposal system remains disorganized and unavailable in the Saint Martin island of Bangladesh. 


\subsection{Responsible Group for Waste Mismanagement in the Study Area}

Waste mismanagement refers to the process or practice for managing waste incompetently or dishonestly. It is observed from the present survey that various groups are responsible for mismanagement of wastes in the study area, which are shown in the following figure 6.

\section{Responsible Groups for Wastes Mismanagement in the Island}

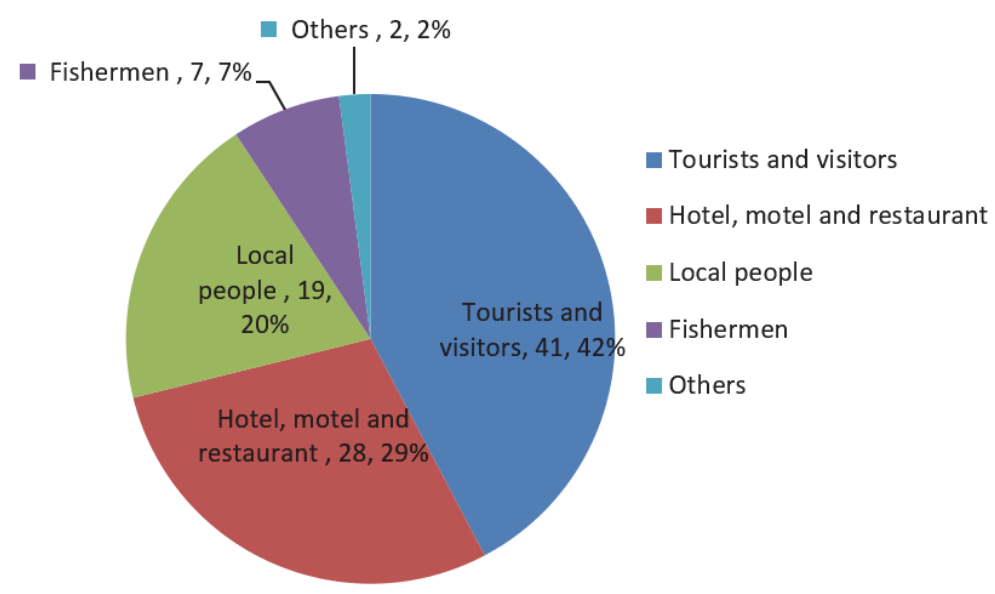

Figure 6. Responsible groups for wastes mismanagement in the study area

Source: Questionnaire Survey, (2015)

It is observed from the above fig.6 that tourists and visitors are the most responsible group (42\%) for waste mismanagement. Besides this, hotel restaurants $(29 \%)$ and local people $(20 \%)$ are also liable for these types of waste mismanagement. Another responsible group is identified namely; the fishermen (7\%) who were used to mismanage by fishing wastes in the island (Figure. 6). During the tourist season (from November to February), it is estimated that on an average about 3000 peoples per day may visit this island that is beyond the holding capacity for this small marine coral island. Through engine boats and ships, a huge amount of crude oil, plastic and other non-biodegradable wastes are discharged into the marine water adjacent to the island. Thus, the quality of islands' coastal water is degrading gradually.

\subsection{Types of Problems Related to Wastes Mismanagement in the Island}

The present study identified the various types of problems that are created by the impolite management of the wastes. The identified problems, which are related to waste mismanagement, are shown in the following figure 7.

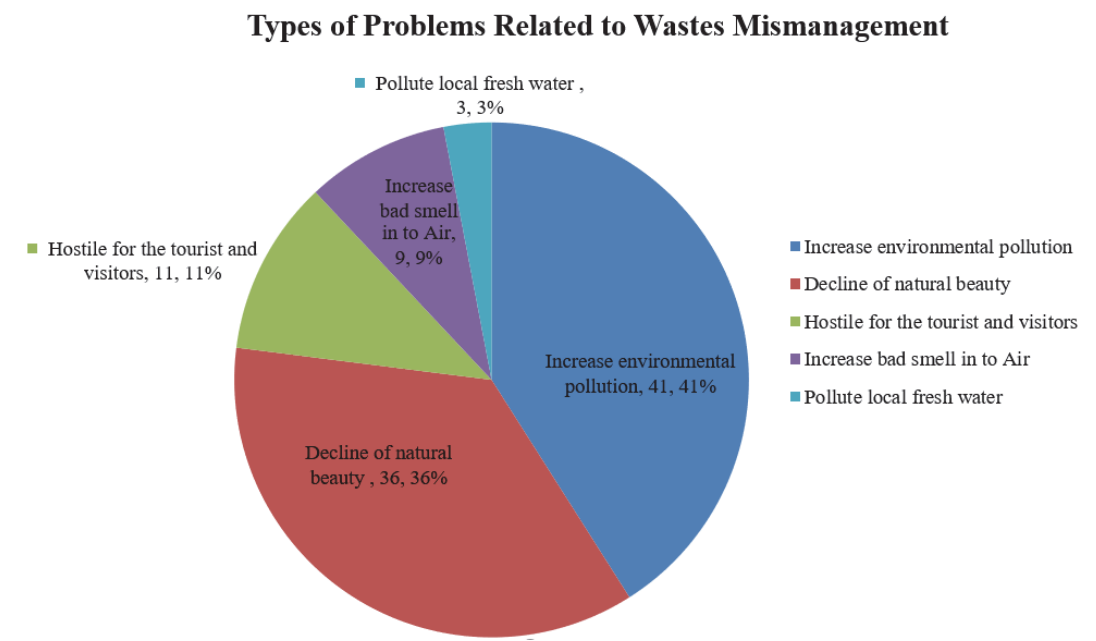

Figure 7. Types of problems related to wastes mismanagement

Source: Questionnaire Survey, (2015) 
It is observed from the above figure. 7 that $41 \%$ respondents have been reported that environmental pollution is increasing due to wastes mismanagement in the island. The problems, which are also related to waste mismanagement declining the natural beauty (36\%), hostile environment for tourist and visitors $(11 \%)$, create bad smell (9\%) and pollute fresh water (3\%), observed respectively (Fig.7). Afrin et al., (2013) also mentioned that the esthetical beauty of this coral island is gradually degrading by improper wastes management.

\subsection{In Response to Take Initiatives Regarding the Wastes and Its Management}

It is observed from the present study $45 \%$ respondents urged that at present some NGOs were supplying portable dustbin to the beach area in the island for short term waste management. Besides it, Local government, local people and hotel owners are also contributing in the waste management activities among the tourist area in the island. In some places of the island, people were used to dump the wastes into earth hole and some of them tried to burn the paper wastes during the winter season. Although all these initiatives are insufficient to manage the increasing volume of wastes in this island but it's a good beginning towards as pollution free environment for this tourist island.

\subsection{Recommendations for Sustainable Development of Saint Martin's Island}

The present study also gathered a lot of information from the expert opinion survey regarding problems and prospects of the Saint Martin's island. To improve the geo-environmental condition of the unique coral island, a set of recommendations have been suggested as follows:

$>$ As the Saint Martin's island is a coral island, it should be preserved as an unaltered ecosystem though most of its part undergone changes.

$>$ As there is no systematic land use of this island, a proper systematic land use plan should be implicated by the Government and related authority.

$>$ Agricultural lands are decreasing due to the expansion of human settlement and tourist facilities. A fixed portion of land should be demarcated for the agricultural practices so that the island could be self-sufficient on its food supply.

$>$ Special area of this island where most of the biodiversity exists or endangered should be kept safe from the human intervention.

$>$ Environmental Impact Assessment (EIA) should be adopted for any infrastructure development in this island.

$>$ A proper planned drainage system should be introduced for the easy exhaustion of wastewater and solving all those problems that resultant from improper drainage of water. Drainage system should be implemented in such a way that which will not result in the siltation, water logging and decrease in the aesthetic beauty of roads.

$>$ Integrated Solid Waste Management Process (ISWMP) could be implemented for the betterment of this island according to the ISWM wastes would be managed by reducing the amount, reusing the products and recycling the non-biodegradable components.

$>$ Use of plastics items by the tourists and inhabitants could have harmful and threat for the coral and other living species. So its use in this island should be prohibited strictly.

$>$ Tourists are the most responsible for waste mismanagement. Therefore, strict laws and regulation should be imposed for the tourists so that not to throw the wastes here and there.

$>$ Waste mismanagement in this island is resulting from the deficiency of the fixed disposal site and lack of bins for throwing the waste. So, sufficient number of closed bins (either permanent or temporary) that will not lead to the spread of bed smell should be introduced throughout the island.

$>$ It should be developed and enforced strict regulations against the use of ground water by hotel operators, and should be implemented a sustainable water use system through rainwater storage.

$>$ It should be arranged some awareness building campaign for local and visitors to minimize pollution, sewage, waste materials, sewerage disposal and waste management system as site requirements.

$>$ Plantation and maintenance of trees around the island can prevent pollution of the island. Unemployed young people might be involved to this activity through GOs and NGOs.

$>$ The island cleaning project has to be designed and implemented under the supervision of the Union Parisad. 


\section{Conclusion}

Saint Martin's island has great contribution in tourism sector of Bangladesh. The Saint Martin's island is the only coral bearing island of Bangladesh. The biodiversity of this island is experiencing tragic change. The Government of Bangladesh has declared the island as an Ecologically Critical Area. Local and national awareness, government and private sectors' cooperation are essential for the conservation and sustainability of this islands' ecosystem. Although waste management in this island is not structured yet but it is light of hope, that few NGO's were tried to initiate some steps for preventing the mismanagement of waste especially during the tourist season. Most of the agricultural lands are transforming to the human settlements, hotels and restaurants. It is high time to take some steps for the systematic management of the land use of this coral island. Besides this, development of drainage system is also a matter of eco-tourism. It should be arranged some awareness building campaign for local and visitors to minimize pollution, sewage, waste materials, sewerage disposal and waste management system as site requirements. Some special area of this island where most of the biodiversity exists or endangered should be kept safe from the human intervention.

\section{References}

(MoEF) Ministry of Environment \& Forest. (1997). The Environment Conservation Rules-1997, Bangladesh Gazette, (2nd ed). Dhaka: Ministry of Environment \& Forest (MoEF), Government of the Peoples Republic of Bangladesh, pp.179-226.

(NACOM) Nature Conservation Management. (2009). Environmental Education for Conservation of Threatened Coral Resources in the St. Martin's Island Project, Final Report, supported by South Asia Co-operative Environment Programme (SACEP) and Department of Environment, Government of Bangladesh, pp.22.

(NCSIP) National Conservation Strategy Implementation Project. (1997). Survey of Fauna : final report on the project "Survey of Fauna" of the National Conservation Strategy Implementation Project-1, Department of Zoology, University of Dhaka: Ministry of Environment and Forest, Government of the Peoples Republic of Bangladesh, pp.324.

Afrin, S., Sultana, N., \& Islam, M. T. (2013). Exploring the Potentials of Culture-friendly Tourism: An Empirical Study in the Saint Martin's Island. American International Journal of Research in Humanities Arts and Social Science, 3(2), 200-204.

Alam, O., Deng, T. I., Uddin, M. N., \& Alamgir, M. (2015). Application of Environmental Ethics for Sustainable Development and Conservation of Saint Martin's Island in Bangladesh. Journal Environmental Sciences \& Natural Resources, 8(1), 19-27.

Alam, S., \& Hassan, M. M. (1998). The Origin of Beach Rock of St.Martin's Island of Bay of Bengal, Bangladesh. Journal Oriental Geographer, 42(2), 21-32.

Asiatic Society of Bangladesh. (2015). Banglapedia: The National Encyclopedia of Bangladesh, ( ${ }^{\text {rd }}$ ed), Dhaka: Asiatic Society of Bangladesh, 9, 414-415.

Feeroz, M. M. (2009). Effects of Environmental Degradation on Food Security in the St. Martin's Island of Bangladesh, Final Report, supported by National Food Policy Capacity Strengthening Programme (NFPCSP), Government of the Peoples Republic of Bangladesh, pp.82.

Hasan, M. M. (2009). Tourism and Conservation of Biodiversity: A Case Study of Saint Martin's Island, Bangladesh. Social Justice and Global Development Journal, 1(1), 1-11.

Hoque, M., Islam, M. A., Ahmed, S. T., \& Hoque, S. M. (1979). Geology of the Saint Martin's Island. Bangladesh Journal of Scientific Research, 2(B), 17- 27.

Hossain, M. M., \& Islam, M. H. (2006). Status of the Biodiversity of Saint Martin's Island, Bay of Bengal, Bangladesh. Pakistan Journal of Marine Sciences, 15(2), 201-210.

Hossain, M. S., Chowdhury, S. R., \& Nabi, M. R. U. (2007). Resource Mapping of Saint Martin's Island Using Satellite Image and Ground Observations. Journal of forestry \& Environment, 5(1), 23-36.

Islam, M. Z. (2002). Marine Turtle Nesting at Saint Martin's Island. Marine Turtles Newsletter, 96, 19-21.

POUSH. (2006). Reconnaissance Social Survey, Community Mobilization for Biodiversity Conservation at Cox's Bazar, Coastal and Wetland Biodiversity Management Project, Coastal and Wetland Biodiversity Management Project no. BGD/99/G31 supported by St. Martin's Island ECA Draft Conservation Management Plan Department of Environment, Dhaka, Bangladesh

Rabby, F. (2016). Environmental and Socio economic condition of Saint Martin's Island (Unpublished MS Study 
report). Department of Geography and Environment, Jahangirnagar University. Savar, Dhaka.

Rahman, M. (2009, December 23). Impact of climate change on Saint Martin's Island', The Daily Star, p.6 Retrieved from http:/www.thedailystar.net/newDesign/news-details.php?nid=120032

Rajasuriya, R. A., Zahir, H., Muley, E. V., Subrimunian, B. R., Venkataraman, W., Wafar, M. V. M., Khan, M. H., \& Whitingham, E. (2000). Status of Coral Reefs in South Asia: Bangladesh, India, Maldives and Sri Lanka', in: Wilkinson, C. (eds), Status of Coral Reefs of the World: 2000, (1 $1^{\text {st }}$ ed). Queensland: Australian Institute of Marine Science, pp. 95-116.

Rashid, H., \& Rob, M. A. (1997, June 6). Narikel Jinjiradwip: Why not declare it a protected area. The Daily Independent (Weekend Magazine, Saint Martin's: An Endangered Natural Park), pp.2-7.

The Daily Star. (2009, February 10). Sea Turtles Washed Ashore Dead' Cox's Bazar correspondent, pp.5.

Tomascik, T. (1997). Management Plan for Coral Resources of Narikel Jinjira (Saint Martin's Island), Final Report, Dhaka: National Conservation Strategy Implementation Project-1, Bangladesh. pp. 27-31.

UNDP. (2010). Environmental Profile of Saint Martin's Island, (1 ${ }^{\text {st }}$ ed). Coastal and Wetlands Biodiversity Management Project, Dhaka: United Nations Development Programme (UNDP), Bangladesh, pp.33-34

Upal N.H. (2015). Environmental Hazards and Conservation Approach to the Biodiversity and Ecosystem of the Saint Martin's Island in Bangladesh. in Raju N., Gossel, W., and Sudhakar, M. (Eds.), Management of Natural Resources in a Changing Environment, ( $1^{\text {st }}$ ed), Springer, Cham, pp.6-20. https://doi.org/10.1007/978-3-319-12559-6_20

\section{Copyrights}

Copyright for this article is retained by the author(s), with first publication rights granted to the journal.

This is an open-access article distributed under the terms and conditions of the Creative Commons Attribution license (http://creativecommons.org/licenses/by/4.0/). 